\title{
The hamster as a model system for the study of influenza vaccines
}

\author{
C. W. PotTer \\ Ph.D. \\ R. JENNINGS \\ Ph.D. \\ University of Sheffield Medical School, Faculty of Medicine, Beech Hill Road, Sheffield
}

\begin{abstract}
Summary
A series of experiments was carried out in hamsters to determine their value as an experimental animal for the study of influenza virus infection and immunization. Hamsters could be infected intranasally with approximately 100 EID $_{50}$ of unadapted influenza $\mathrm{A} /$ Port Chalmers/73 virus; infection produced serum HI antibody and virus was recovered from both nasal washings and from lungs. Inoculation of hamsters with influenza virus or inactivated influenza virus vaccine produced immunity to subsequent homologous virus challenge. Groups of hamsters were inoculated with graded doses of a number of different inactivated influenza vaccines: the serum HI antibody response varied greatly for the different vaccines. For some influenza vaccines, the antibody response of hamsters was promoted by prior heterotypic influenza virus infection, but in primed animals the same, wide variation in serum antibody response to different influenza virus vaccines remained. Using the hamster as an experimental model, 60 i.u. of an inactivated $\mathrm{A} /$ England/42/72 vaccine gave protection against challenge virus infection; however, 600 i.u. of surface antigen material, including only haemagglutinin and neuraminidase failed to give protection. Inoculation of hamsters with subunit antigens absorbed to alhydrogel gave immunity to challenge virus infection.
\end{abstract}

\section{Introduction}

Influenza A viruses have been shown to infect mice, hamsters, guinea-pigs, ferrets, dogs and monkeys (Smith, Andrewes and Laidlaw, 1933; Taylor and Parodi, 1942; Schulman and Kilbourne, 1965; Todd and Cohen, 1968; Berendt, 1974), and any of these species could be used in the study of human influenza vaccines. The ferret is probably the species which offers most advantages for these studies, since ferrets are easily infected with small quantities of unadapted virus and produce a clinical response to influenza virus infection similar to that in man and which can be quantified (Smith et al., 1933; Haff, Shriver and Stewart, 1966; Potter et al., 1972); however, these animals are relatively large and expensive to house, breed only once or twice a year, and there are no inbred lines of ferret which would give more reproducible immune responses. For these reasons ferrets have not been used to a large extent for the study of influenza vaccines, and some of the same limitations apply to dogs and monkeys. The most commonly used animal in the study of influenza vaccines is the mouse; these animals are relatively inexpensive to keep, breed prolifically and can be obtained as inbred lines. On the other hand, influenza virus infection of mice is predominantly a lower respiratory tract infection requiring in many cases the use of mouse-adapted virus; thus, the infection is distinct from that of man. In addition, losal antibody in mice can be induced by pathotopic potentiation (Fazekas de St Groth and Donnelley, 1950) and live influenza virus infection has been reported to give immunity to heterotypic virus (Schulman and Kilbourne, 1965; Werner, 1966); since neither of these phenomena have been reported in man, mice may not be a satisfactory model for the study of human vaccines. For the above reasons, a series of experiments has been carried out to determine the value of hamsters in the study of influenza virus vaccines.

\section{Materials and methods \\ Animals}

Syrian hamsters were obtained from a single, randomly-bred colony at the University of Sheffield. The animals were weaned at 4 weeks of age, and used for experimentation at 6-12 weeks of age when the weight was $50-70 \mathrm{~g}$.

\section{Influenza viruses and virus vaccines}

Influenza virus $\mathrm{A} / \mathrm{FM} / \mathrm{1} / 47\left(\mathrm{H}_{1} \mathrm{~N}_{1}\right)$ and $\mathrm{A} /$ England/ $42 / 72\left(\mathrm{H}_{3} \mathrm{~N}_{2}\right)$ were kindly supplied by $\mathrm{Dr} \mathrm{G}$. C. Schild, National Institute for Medical Research, Mill Hill, London. Virus pools were prepared by the allantoic inoculation of 10-day embryonated eggs. After incubation for $48 \mathrm{hr}$ at $33^{\circ} \mathrm{C}$, the allantoic fluids were harvested and stored at $-80^{\circ} \mathrm{C}$. The identity of the viruses was confirmed by cross-HI tests using monospecific ferret antisera.

Monovalent influenza virus A/PR/8/34 $\left(\mathrm{H}_{0} \mathrm{~N}_{1}\right)$, A/FM/1/47 $\left(\mathrm{H}_{1} \mathrm{~N}_{1}\right)$, A/Japan/305/57 $\left(\mathrm{H}_{2} \mathrm{~N}_{2}\right)$ and A/Hong Kong/1/68 $\left(\mathrm{H}_{3} \mathrm{~N}_{2}\right)$ vaccines were obtained from Professor W. M. Marine, Emory University, 
Atlanta, Georgia, U.S.A. These vaccines were prepared by Merrell-National Laboratories, Swiftwater, Pennsylvania, U.S.A., by formaldehyde treatment of virus purified by zonal centrifugation. Inactivated influenza virus $A /$ England/42/72 vaccine, the purified surface antigen material derived from this virus and the surface antigen absorbed to alhydrogel were obtained from Dr I. Furminger, Evans Biologicals Ltd, Speke, Liverpool; the production of these materials has been described previously (Brady, Furminger and Stones, 1976).

\section{Experimental design}

Before immunization, a 1-2 ml sample of blood was collected from each hamster from the retroorbital sinus. Groups of animals were then inoculated i.m. with an inactivated influenza virus vaccine in a $0.5 \mathrm{ml}$ volume of phosphate buffered saline (PBS), or infected with live virus. For virus infection, the hamsters were lightly anaesthetized with ether, and the virus was given dropwise, intranasally in a $0.2 \mathrm{ml}$ volume. Three weeks later, a second blood sample was taken, and the animals were inoculated intranasally with a challenge infection of live virus in a $0.2 \mathrm{ml}$ volume. Some animals from each group were killed 3 days following the challenge infection when the lungs were removed and ground with carborundum powder in PBS to give a $40 \%(\mathrm{w} / \mathrm{v})$ suspension. The lung suspensions were centrifuged at $2500 \mathrm{~g}$ for 10 $\mathrm{min}$, and the supernatant fluids titrated for infective virus. In one experiment, nasal washings were obtained 3 days after challenge infection and titrated for virus. These washings were obtained by holding the hamster by the skin at the back of the neck sufficiently tightly to induce the animal to gape. One millilitre of PBS containing $2 \%(\mathrm{v} / \mathrm{v})$ bovine serum albumin and antibiotics was then introduced dropwise into the nose and collected with a pipette when the fluid had drained into the buccal cavity. All surviving hamsters were bled 3 weeks after the challenge infection.

\section{Virus isolation}

Lung suspensions and nasal washings were stored at $-80^{\circ} \mathrm{C}$ before testing. The titres of virus in these specimens were determined by titration using the allantois-on-shell (AOS) method (Fazekas de Groth, Withell and Lafferty, 1958). Shell fragmen from four eggs were used for each titration, to oveecome variations in the sensitivity of eggs to influenza: virus infection.

\section{Haemagglutinin-inhibiting (HI)antibody tests}

Serum specimens were treated with cholera filtrats (Burroughs Wellcome Ltd) for $18 \mathrm{hr}$ at $37^{\circ} \mathrm{C}$, an $\overline{\mathrm{A}}$ subsequently heated for $60 \mathrm{~min}$ at $56^{\circ} \mathrm{C}$. Following this treatment, the specimens were titrated for $\mathrm{HI}$ antibody using the microtitre method (Sever, 1962 P as described previously (Potter et al., 1973a).

\section{Neuraminidase-inhibiting (NI) antibody tests}

The titre of NI antibody in hamster sera wa. determined using the standard World Healtis Organization (WHO) methods, with WHO standare reagents (Aymard-Henry et al., 1973).

\section{Results}

Response of hamsters to influenza virus A/England 42/72 infection

Groups of hamsters were infected intranasal $\square$ with dilutions of influenza virus $A /$ England/42/72 a $0.2 \mathrm{ml}$ volume of PBS. The titres of virus recovere 3 days post-infection from lung suspensions and fom nasal washings, together with the changes in serim HI antibody titre, are shown in Table 1. Virus giras recovered from lung suspensions and nasal washing taken 3 days after infection with $10^{1 \cdot 5}-10^{4 \cdot 5}$ EID of A/England/42/72 virus. In addition, all these animals developed serum $\mathrm{HI}$ antibody after virus infection. No obvious signs of lung consolidatio $\vec{B}$ were seen in influenza virus-infected hamsters, and the quantity of virus isolated from lung suspensions was relatively small compared to that found in nas washings. No evidence of virus infection was found in hamsters given $10^{0.5} \mathrm{EID}_{50}$ of virus. Thus, ham. sters were successfully infected with a dose of England/42/72 virus which was similar to that re quired to infect ferrets (Potter, unpublished result

Rectal temperatures were taken twice daily for 3 days following $\mathrm{A} /$ England/42/72 virus infection, bu no significant increase in temperature was recorded for any individual animal. Nasal washings were.

TABLE 1. Titration of $A /$ England/42/72 influenza virus in hamsters

\begin{tabular}{|c|c|c|c|c|}
\hline \multirow{2}{*}{$\begin{array}{l}\text { Virus } \\
\text { inoculum } \\
\left(\log \text { EID }_{50}\right)\end{array}$} & \multirow{2}{*}{$\begin{array}{l}\text { No. of } \\
\text { hamsters } \\
\text { tested }\end{array}$} & \multicolumn{2}{|c|}{ Virus recovered (mean titre $\log \mathrm{EID}_{50} / \mathrm{ml}$ ) } & \multirow{2}{*}{$\begin{array}{c}\text { Serum HI } \\
\text { antibody response } \\
\text { (geometric mean titre) }\end{array}$} \\
\hline & & Nasal washings & Lung suspension & \\
\hline $\begin{array}{l}10^{4.5} \\
10^{3.5} \\
10^{2.5} \\
10^{1.5} \\
10^{0.5}\end{array}$ & $\begin{array}{l}5 \\
5 \\
5 \\
6 \\
4\end{array}$ & $\begin{aligned} 5 \cdot 18 \\
>5 \cdot 80 \\
4 \cdot 31 \\
3 \cdot 44 \\
<0 \cdot 5\end{aligned}$ & $\begin{aligned} 4 \cdot 78 \\
4 \cdot 46 \\
5 \cdot 30 \\
2 \cdot 30 \\
<0 \cdot 5\end{aligned}$ & $\begin{array}{ll}<10- & 24 \\
<10- & 38 \\
<10- & 47 \\
<10- & 38 \\
<10-<10\end{array}$ \\
\hline
\end{tabular}


TABLE 2. Infection of hamsters with challenge influenza virus following immunization or infection

\begin{tabular}{|c|c|c|c|c|}
\hline \multirow[b]{2}{*}{ Treatment of hamsters } & \multirow{2}{*}{$\begin{array}{l}\text { No. } \\
\text { tested }\end{array}$} & \multirow{2}{*}{$\begin{array}{l}\text { Serum HI response } \\
\text { (geometric mean titre) }\end{array}$} & \multicolumn{2}{|c|}{ Virus recovery after challenge ${ }^{*}$} \\
\hline & & & $\mathrm{A} / \mathrm{FM} / 1 / 47$ & A/England $/ 42 / 72$ \\
\hline Infection with $\mathrm{A} / \mathrm{FM} / 1 / 47$ & 4 & $<10-285$ & $<10^{1.0}$ & $10^{2.70}$ \\
\hline $\begin{array}{l}\text { Inact. } A / F M / 1 / 47 \text { vaccine } \\
\text { ( } 250 \text { i.u.) }\end{array}$ & 4 & $<10-149$ & $<10^{1.0}$ & $10^{3.46}$ \\
\hline $\begin{array}{l}\text { Inact. } A / F M / 1 / 47 \text { vaccine } \\
\text { ( } 25 \text { i.u.) }\end{array}$ & 4 & $<10-\quad 27$ & $10^{1.94}$ & $10^{2.70}$ \\
\hline $\begin{array}{l}\text { Inact. } A / F M / 1 / 47 \text { vaccine } \\
\text { (25 i.u.) + FCA }\end{array}$ & 4 & $<10-307$ & $<10^{1.0}$ & NT \\
\hline Nil & 4 & $<10-<10$ & $10^{2 \cdot 2}$ & $10^{2 \cdot 94}$ \\
\hline
\end{tabular}

* Titre of virus $\log \mathrm{EBID}_{50} / \mathrm{ml}$ in $40 \%$ lung suspension prepared 3 days after challenge infection.

TABLE 3. Serum antibody response of hamsters to immunization with inactivated influenza virus vaccines

\begin{tabular}{cccccc}
\hline $\begin{array}{l}\text { Vaccine } \\
\text { dose } \\
\text { (i.u.) }\end{array}$ & A/PR/8/34 & A/FM/1/47 & A/Jap/305/57 & A/Hong Kong/68 & A/England/42/72 \\
\cline { 2 - 6 } & NT & NT & $<10-<10^{*}$ & $<10-36$ & $<10-21$ \\
$800-1500$ & $<10-26$ & NT & $<10-<10$ & $<10-<10$ & $<10-10$ \\
$200-500$ & $<10-<10$ & $<10-58$ & NT & $<10-<10$ & $<10-<10$ \\
$50-150$ & $<10-<10$ & $<10-<10$ & NT & NT & NT \\
$5-10$ & NT & $<10-<10$ & NT & NT & NT \\
$<5$ & &
\end{tabular}

* Serum HI antibody response to immunization (geometric mean titre of four or more hamsters). NT, not tested.

collected on alternate days from 3 days following infection. These specimens were tested for neutralizing antibody by the AOS technique (Fazekas de St Groth et al., 1958) but no detectable local antibody was found following infection.

\section{Effect of challenge infection on hamsters immunized with influenza virus or inactivated influenza virus vaccine}

Groups of hamsters were either infected intranasally with influenza virus $\mathrm{A} / \mathrm{FM} / 1 / 47$ or inoculated i.m. with inactivated $A / F M / 1 / 47$ vaccine; the serum antibody response and the resistance of these animals to challenge infection was determined 3 weeks later. The results are shown in Table 2 . All hamsters infected with $\mathrm{A} / \mathrm{FM} / 1 / 47$ virus developed homologous serum HI antibody (geometric mean titre (g.m.t.) $1: 265$ ) and were immune to challenge virus infection with $\mathrm{A} / \mathrm{FM} / 1 / 47$ virus, since no infective virus was recovered from $40 \%$ lung suspensions prepared 3 days after challenge virus infection. However, hamsters previously infected with influenza virus $A / F M /$ $1 / 47$ were susceptible to intranasal infection with A/England/42/72 virus (Table 2). Hamsters inoculated intramuscularly with 250 i.u. of inactivated A/FM/1/47 vaccine developed serum $\mathrm{HI}$ antibody (g.m.t. $1: 149$ ) and were immune to challenge infection. In contrast, hamsters given 25 i.u. of $\mathrm{A} / \mathrm{FM} / \mathbf{1}$ 47 vaccine developed serum $\mathrm{HI}$ antibody in this experiment (g.m.t. $1: 27$ ); the antibody titres were relatively low, and the animals were susceptible to challenge infection with homologous virus (Table 2). This result was probably due to the low titre of serum antibody induced by 25 i.u. of inactivated vaccine, since when this dose of vaccine was given with Freund's complete adjuvant (FCA), high titres of serum $\mathrm{HI}$ antibody were produced, and the hamsters were immune to challenge infection. None of the hamsters given inactivated $\mathrm{A} / \mathrm{FM} / 1 / 47$ vaccine showed any evidence of immunity to challenge infection with $A /$ England/42/72 virus.

Serum HI antibody response of hamsters to inactivated influenza virus vaccines

Various inactivated influenza virus vaccines were titrated in groups of hamsters; the vaccines were given i.m. in a $0.5 \mathrm{ml}$ volume of PBS, and the animals were bled 3 weeks later. The results are shown in Table 3. Since the series of dilutions tested varied for the different vaccines, Table 3 shows the number of international units of vaccine given to hamsters grouped under five headings. A serum HI antibody response was found in hamsters inoculated with 50-150 i.u. of inactivated A/FM/1/47 vaccine, but larger doses were required for all other vaccines. Thus, hamsters inoculated with less than 200-500 i.u. of $\mathrm{A} /$ England/42/72 or $\mathrm{A} / \mathrm{PR} / 8 / 34$ vaccine, or less than $800-1500$ i.u. of $A / H o n g$ Kong/68 vaccine 
TABLE 4. Serum antibody response of hamsters to immunization with inactivated influenza vaccine, following infection with $\mathrm{A} / \mathrm{FM} / 1 / 47$ virus

\begin{tabular}{ccccc}
\hline \multirow{2}{*}{$\begin{array}{c}\text { Vaccine } \\
\text { dose } \\
\text { (i.u.) }\end{array}$} & A/PR/8/34 & A/Jap/305/57 & A/Hong Kong/68 & A/England/42/72 \\
\cline { 2 - 5 } & NT & $<10-19 *$ & NT & $<10-73$ \\
\hline $800-1500$ & NT & $<10-<10$ & NT & NT \\
$200-500$ & $<10-28$ & $<10-<10$ & $<10-19$ & $<10-$ \\
$50-150$ & $<10-<10$ & NT & $<10-23$ & $<10-<10$ \\
$5-10$ & NT & NT & $<10-<10$ & $<10-<10$ \\
$<5$ & &
\end{tabular}

* Serum HI antibody response to immunization (geometric mean titre of four or more hamsters). NT, not tested.

failed to develop serum $\mathrm{HI}$ antibody. No detectable serum HI antibody was induced in hamsters inoculated with $800-1500 \mathrm{i}$.u. of A/Japan/305/57 vaccine, although one-tenth the dose of influenza A/FM/1/47 vaccine induced serum antibody. These results suggest that either the method of standardization by i.u. is inaccurate or that the vaccines differ markedly in immunogenicity.

Serum HI antibody response of hamsters to inactivated influenza virus vaccine, following prior infection with $A / F M / 1 / 47$ virus

Previous studies have shown that the response of animals to inactivated influenza virus vaccines was enhanced by prior, heterotypic influenza virus infection (Potter et al., 1973; Jennings, Potter and McLaren, 1974). To test further the immunogenicity of different influenza virus vaccines, these vaccines were titrated in groups of hamsters which had been infected intranasally with $\mathrm{A} / \mathrm{FM} / 1 / 47$ virus 3 weeks before immunization; this prior infection did not induce detectable serum HI antibody to any of the inactivated influenza virus vaccines tested. The results are shown in Table 4. Hamsters previously infected with $\mathrm{A} / \mathrm{FM} / 1 / 47$ virus produced detectable levels of serum HI antibody in response to immunization with smaller doses of inactivated virus vaccine than required by normal hamsters. Thus, serum HI antibody was detected in hamsters inoculated with $800-1500$ i.u. of $A / J a p a n / 305 / 57$ vaccine, $50-150$ i.u. of $A / P R / 8 / 34$ vaccine and $A /$ England/42/72 vaccine, and 5-10 i.u. of A/Hong Kong/68 virus (Table 4). Although hamsters previously infected with heterotypic influenza viruses produced serum antibody in response to smaller doses of vaccine than normal hamsters, there were in both cases large differences in the immunogenicity of the different vaccines tested.

\section{Titration of inactivated A/England/42/72 virus vaccine in hamsters}

Groups of normal hamsters were test bled and inoculated intramuscularly with varying doses of inactivated $\mathrm{A} /$ England/42/72 whole virus vaccine in saline. Three weeks after immunization, serum specimens were taken and tested for $\mathrm{HI}$ and NI antibodies to the vaccine virus, and the hamsters were inoculated intranasally with $\mathrm{A} /$ England/42/72 virus; lung suspensions were collected 3 days later and titrated for virus. The results are shown in Table 5 . Five of six hamsters immunized with 600 i.u. and two of six hamsters immunized with 60 i.u. of vaccine produced demonstrable HI antibody. Virus was not recovered from lung suspensions collected 3 days after challenge infection of hamsters immunized with 600 or 60 i.u. of A/England/42/72 vaccine, but virus was recovered from hamsters immunized with 6.0 or 0.6 i.u. (Table 5). Immunization of hamsters with 60 i.u. or more of vaccine produced serum HI antibody and immunity to homologous challenge infection.

\section{Titration of $A /$ England/42/72 surface antigens in hamsters}

Groups of hamsters were inoculated with different concentrations of purified haemagglutinin and neuraminidase antigens in saline prepared from influenza virus $A /$ England/42/72. Three weeks later, the animals were bled and inoculated intranasally with A/England/42/72 virus. The results are shown in Table 6. Serum HI antibody was produced in all hamsters inoculated with 600 i.u. of subunit material, and in four of six animals inoculated with 60 i.u. of vaccine; two hamsters inoculated with 600 i.u. of vaccine also developed NI antibody. The antibody response to immunization was similar to that obtained for whole virus vaccine (Table 5); however, in contrast to the results obtained with whole virus, none of the hamsters inoculated with 600 i.u. or less of surface antigen material showed immunity to challenge infection with homologous $A /$ England/42/ 72 virus, since infective virus was recovered from lung suspensions from all groups of hamsters (Table 6). This lack of immunity was observed for hamsters with serum HI antibody titres comparable to that found in hamsters given whole virus vaccine and which were immune to challenge infection. 
TABLE 5. Response of hamsters to immunization with influenza A/England/42/72 whole virus vaccine

\begin{tabular}{|c|c|c|c|c|}
\hline $\begin{array}{l}\text { Vaccine } \\
\text { dose } \\
\text { (i.u.) }\end{array}$ & $\begin{array}{c}\text { Hamster } \\
\text { no. }\end{array}$ & $\begin{array}{l}\text { HI antibody } \\
\text { response to } \\
\text { A/Eng/42/72 }\end{array}$ & $\begin{array}{l}\text { NI antibody } \\
\text { response to } \\
\text { A/Eng/42/72 }\end{array}$ & $\begin{array}{l}\text { Virus recovery } \\
\text { after challenge } \\
\left(\log _{10} / \mathrm{ml}\right)^{*}\end{array}$ \\
\hline 600 & $\begin{array}{l}1 \\
2 \\
3 \\
4 \\
5 \\
6\end{array}$ & $\begin{array}{c}<10-60 \\
<10-20 \\
- \\
<10-60 \\
<10-30 \\
<10-15\end{array}$ & $\begin{array}{l}-\dagger \\
- \\
- \\
- \\
-\end{array}$ & $<0.50$ \\
\hline 60 & $\begin{array}{l}1 \\
2 \\
3 \\
4 \\
5 \\
6\end{array}$ & $\begin{array}{c}<10-30 \\
- \\
- \\
<10-15 \\
- \\
-\end{array}$ & $\begin{array}{c}- \\
<10-20 \\
- \\
- \\
- \\
-\end{array}$ & $<0.50$ \\
\hline 6 & $\begin{array}{l}1 \\
2 \\
3 \\
4 \\
5 \\
6\end{array}$ & $\begin{array}{l}- \\
- \\
- \\
- \\
- \\
-\end{array}$ & $\begin{array}{l}- \\
- \\
- \\
-\end{array}$ & $2 \cdot 15$ \\
\hline Nil & $\begin{array}{l}1 \\
2 \\
3 \\
4 \\
5 \\
6\end{array}$ & $\begin{array}{l}- \\
- \\
- \\
- \\
- \\
-\end{array}$ & $\begin{array}{l}- \\
- \\
- \\
- \\
- \\
-\end{array}$ & $4 \cdot 46$ \\
\hline
\end{tabular}

* Virus estimated by allantois-on-shell titrations of pooled, $40 \%$ hamster lung suspensions. $\dagger<10-<10$.

TABLE 6. Response of normal hamsters to immunization with influenza A/England/42/72 haemagglutinin and neuraminidase

\begin{tabular}{|c|c|c|c|c|}
\hline $\begin{array}{l}\text { Antigen } \\
\text { dose } \\
\text { (i.u.) }\end{array}$ & $\begin{array}{c}\text { Hamster } \\
\text { no. }\end{array}$ & $\begin{array}{l}\text { HI antibody } \\
\text { response to } \\
\text { A/Eng/42/72 }\end{array}$ & $\begin{array}{l}\text { NI antibody } \\
\text { response to } \\
\mathrm{A} / \text { Eng/42/72 }\end{array}$ & $\begin{array}{l}\text { Virus recovery } \\
\text { after challenge } \\
\left(\log _{10} / \mathrm{ml}\right)^{*}\end{array}$ \\
\hline 600 & $\begin{array}{l}1 \\
2 \\
3 \\
4 \\
5 \\
6\end{array}$ & $\begin{array}{c}<10-15 \\
<10-20 \\
<10-20 \\
<10-15 \\
\text { ND } \\
\text { ND }\end{array}$ & $\begin{array}{c}<10-120 \\
<10-40 \\
- \\
- \\
\text { ND } \\
\text { ND }\end{array}$ & $2 \cdot 96$ \\
\hline 60 & $\begin{array}{l}1 \\
2 \\
3 \\
4 \\
5 \\
6\end{array}$ & $\begin{array}{c}<10-10 \\
<10-10 \\
<10-40 \\
-\dagger \\
<10-15 \\
-\end{array}$ & $\begin{array}{l}- \\
- \\
- \\
- \\
- \\
-\end{array}$ & $3 \cdot 06$ \\
\hline 6 & $\begin{array}{l}1 \\
2 \\
3 \\
4 \\
5 \\
6\end{array}$ & $\begin{array}{l}- \\
- \\
- \\
- \\
- \\
-\end{array}$ & $\begin{array}{l}- \\
- \\
- \\
- \\
- \\
-\end{array}$ & $4 \cdot 80$ \\
\hline $0 \cdot 6$ & $\begin{array}{l}1 \\
2 \\
3 \\
4 \\
5 \\
6\end{array}$ & $\begin{array}{l}- \\
- \\
- \\
- \\
- \\
-\end{array}$ & $\begin{array}{l}- \\
- \\
- \\
- \\
-\end{array}$ & $4 \cdot 46$ \\
\hline
\end{tabular}

* Virus estimated by allantois-on-shell titrations of pooled, $40 \%$ hamster lung suspensions. $\dagger<10-<10$.

ND, not done. 
TABLE 7. Response of hamsters to immunization with A/England/42/72 subunits absorbed to alhydrogel

\begin{tabular}{|c|c|c|c|c|}
\hline $\begin{array}{l}\text { Vaccine } \\
\text { dose } \\
\text { (i.u.) }\end{array}$ & $\begin{array}{c}\text { Hamster } \\
\text { no. }\end{array}$ & $\begin{array}{l}\text { HI antibody } \\
\text { response to } \\
\text { A/Eng/42/72 }\end{array}$ & $\begin{array}{l}\text { NI antibody } \\
\text { response to } \\
\text { A/Eng/42/72 }\end{array}$ & $\begin{array}{l}\text { Virus recovery } \\
\text { after challenge } \\
\left(\log _{10} / \mathrm{ml}\right)^{*}\end{array}$ \\
\hline 600 & $\begin{array}{l}1 \\
2 \\
3 \\
4\end{array}$ & $\begin{array}{l}<10-30 \\
<10-30 \\
<10-15 \\
<10-20\end{array}$ & $\begin{array}{l}<10-160 \\
<10-240 \\
<10-240 \\
<10-160\end{array}$ & $<0.50$ \\
\hline 60 & $\begin{array}{l}1 \\
2 \\
3 \\
4\end{array}$ & $\begin{array}{c}<10-30 \\
<10-15 \\
-\dagger \\
-\end{array}$ & $\begin{array}{c}<10-240 \\
<10-20 \\
<10-240 \\
\quad \text { ND }\end{array}$ & $<0.50$ \\
\hline 6 & $\begin{array}{l}1 \\
2 \\
3 \\
4\end{array}$ & $\begin{array}{l}- \\
- \\
- \\
-\end{array}$ & $\begin{array}{c}<10-160 \\
<10-240 \\
<10-20 \\
-\end{array}$ & $4 \cdot 02$ \\
\hline 0.6 & $\begin{array}{l}1 \\
2 \\
3 \\
4\end{array}$ & $\begin{array}{l}- \\
- \\
- \\
-\end{array}$ & $\begin{array}{l}- \\
- \\
- \\
-\end{array}$ & $4 \cdot 80$ \\
\hline
\end{tabular}

* Virus estimated by allantois-on-shell titrations of pooled, $40 \%$ hamster lung suspensions. $+<10-<10$.

ND, not done.

Titration of A/England/42/72 surface antigen absorbed vaccine in hamsters

Groups of hamsters were inoculated i.m. with graded doses of purified A/England/42/72 haemagglutinin and neuraminidase antigens absorbed to an alhydrogel carrier. The serum antibody response to immunization and the immunity to subsequent challenge infection with $\mathrm{A} /$ England/42/72 virus is shown in Table 7. All hamsters inoculated with 600 i.u. of vaccine and two of four animals inoculated with 60 i.u. of vaccine developed demonstrable serum HI antibody; in addition, all hamsters given 600 or 60 i.u. of vaccine and three of four animals given $6 \cdot 0$ i.u. of vaccine developed NI antibody. Thus, the serum $\mathrm{HI}$ antibody response to immunization was similar to that found following immunization with whole virus vaccine, but the absorbed vaccine produced a better NI antibody response. Following challenge infection, virus was not recovered from the lungs of hamsters immunized with 600 or 60 i.u. of surface antigen absorbed vaccine, but virus was recovered from hamsters inoculated with 6.0 i.u. of vaccine. These results show that the degree of immunity induced by the absorbed vaccine was comparable to that induced by whole virus vaccine. The enhanced production of NI antibody induced by the surface antigen absorbed vaccine did not increase the immunity of hamsters to challenge infection, since hamsters given 6.0 i.u. of surface antigen absorbed vaccine produced detectable serum NI antibody but not $\mathrm{HI}$ antibody, and these animals were susceptible to challenge virus infection (Table 7).

\section{Discussion}

The present results suggest that hamsters masobs useful in the study of influenza virus infection ond influenza virus vaccines. The use of ferrets for routine purposes is prohibitively expensive, although this species is possibly the best model for influenza man (Haff et al., 1966; Potter et al., 1972). Hamste breed easily and are relatively inexpensive to mair tain. These animals are closely related, since $\vec{a} \mathbf{m}$ hamsters in this country originate from a single litter, and this would suggest that results obtained these animals are reproducible. Influenza virus infection of hamsters is primarily an upper respirato tract infection; high titres of virus can be obtained from nasal washings, and this, together with the size of the animal, allows serial observations to be made on single animals. In a consideration of suitab? animal models to study influenza virus vaccine and immunity to influenza, hamsters may offer some advantage; however, further studies are required determine if the results obtained in this species a a indicative of those in man.

The results of the present study show that hansters were infected with approximately 30 EID $_{50}$ 영 influenza virus A/England/42/72; in other studiés, hamsters were infected with $100 \mathrm{EID}_{50}$ of $\mathrm{A} / \mathrm{POIt}$ Chalmers $/ 73\left(\mathrm{H}_{3} \mathrm{~N}_{2}\right)$ virus. Titrations of these virus gave similar results in ferrets, and this indicated the the animal species are of equal susceptibility to infection with unadapted virus. Unlike ferrets, howevef, hamsters did not produce a febrile response to infetion, and no local antibody was detectable in nagi 1 
washings taken after infection with A/England/42/72 virus. Both infection and immunization of hamsters with inactivated vaccines induced immunity to homologous challenge virus infection, but not to challenge with heterotypic influenza virus. In this respect, hamsters differ from mice in which heterotypic immunity has been reported following infection with live influenza viruses (Schulman and Kilbourne, 1965; Werner, 1966). There are no data on heterotypic immunity to influenza virus infection in man, and therefore which of the animal results, either those of hamsters or mice, is more akin to the human reaction remains to be determined.

The titration of inactivated influenza virus vaccines in hamsters showed very large differences in the immunogenicity of the vaccines; these differences were apparent in both normal hamsters and in hamsters primed by heterotypic influenza virus infection (Jennings et al., 1974). Thus, serum HI antibody was found in hamsters inoculated with 50-150 i.u. of $\mathrm{A} / \mathrm{FM} / 1 / 47$ virus, but not in animals inoculated with 1500 i.u. of $\mathrm{A} / \mathrm{Japan} / 305 / 57$ vaccine. These differences may be due to either the vagaries of standardization by international units or differences in the immunogenicity of the various influenza virus vaccines tested.

In a study of an inactivated A/England/42/72 vaccine, 600 chick cell agglutination units (CCA) or $60 \mathrm{CCA}$ of whole virus vaccine gave protection against homologous challenge infection; however, immunization with purified virus haemagglutinin and neuraminidase induced similar levels of serum $\mathrm{HI}$ antibody but failed to give immunity. The reason for this is not known; the influenza virus subunit material may have failed to induce serum antibodies to other important antigenic components of the virus which were discarded during purification. This seems unlikely as the subunit vaccine absorbed to alhydrogel induced both serum antibody and immunity comparable to that induced by whole virus vaccine. Alternatively, the purified virus subunit material may have failed to stimulate an important component of the immune reaction, such as cellular immunity, which is required for immunity to challenge virus infection.

\section{References}

Aymard-Henry, M., Coleman, M.T., Dowdle, W.R., LAver, W.G. \& Webster, R.G. (1973) Influenza virus neuraminidase and neuraminidase-inhibition test procedures. Bulletin of the World Health Organization, 48, 199.

BERENDT, R.F. (1974) Simian model for the evaluation of immunity to influenza. Infection and Immunity, 9, 101.

Brady, M.I., Furminger, I.G.S. \& Stones, P.B. (1975) An adsorbed surface-antigen influenza vaccine and its serological astivity in volunteers. Postgraduate Medical Journal, 52, 369.

Fazekas De St Groth, S. \& Donnelley, M. (1950) Studies in experimental immunology of influenza. V. Enhancement of immunity by pathotopic vaccination. Australian Journal of Experimental Biology, 28, 77.

Fazekas De St Groth, S., Withell, J. \& Lafferty, K.J. (1958) An inproved assay for neutralization antibodies against influenza viruses. Journal of Hygiene, 56, 415.

Haff, R.F., Shriver, P.W. \& Stewart, R.C. (1966) Pathogenesis of influenza in ferrets. Nasal manifestations of disease. British Journal of Experimental Pathology, 48, 435.

Jennings, R., Potter, C.W. \& McLaren, C. (1974) Effect of preinfection and preimmunization on the serum antibody response to subsequent immunization with heterotypic influenza vaccines. Journal of Immunology, 113, 1834.

Potter, C.W., Oxford, J.S., Shore, S.L., Mclaren, C. \& StUART-HaRris, C.H. (1972) Immunity to influenza in ferrets. I. Response to live and killed virus. British Journal of Experimental Pathology, 53, 168.

Potter, C.W., Jennings, R., Marine, W.M. \& McLaren, C. (1973a) Potentiation of the antibody response to inactivated A2/Hong Kong vaccines by previous heterotypic influenza virus infection. Microbios, 8, 101.

Potter, C.W., Jennings, R., Rees, R.C. \& Mclaren, C. (1973b) Antibody response of hamsters to A2/Hong Kong virus vaccine after priming with heterotypic virus infection. Infection and Immunity, 8, 137.

Sever, J.L. (1962) Application of a microtechnique to viral serological investigations. Journal of Immunology, 88, 320.

Schulman, J.L. \& Kilbourne, E.D. (1965) Induction of partial specific heterotypic immunity in mice by a single infection with influenza A virus. Journal of Bacteriology, 89, 170.

Smith, W., Andrewes, C.H. \& Laidlaw, P.P. (1933) A virus obtained from influenza patients. Lancet, ii, 66 .

TAYlor, R.M. \& PAROdi, A.S. (1942) Use of hamsters (Cricetus auratus) for detection of influenza virus in throat washings. Proceedings of the Society for Experimental Biology and Medicine, 49, 105.

TodD, J.D. \& Cohen, D. (1968) Study of influenza in dogs. I. Susceptibility of dogs to natural and experimental infection with human A2 and B strains of influenza virus. American Journal of Epidemiology, 87, 426.

WERNER, G.H. (1966) Immunité croisée hétérotypique chez la souris entre virus grippaux humains de types A et A2. Comptes Rendus des Séances de l'Académie des Sciences. Paris, 264, 1913. 